\title{
IMPACT OF THE JAKARTA - SURABAYA HIGH - SPEED TRAIN ON PASSENGERS OF THE JAKARTA - SURABAYA EXECUTIVE TRAIN CORRIDOR
}

\section{PENGARUH KERETA CEPAT JAKARTA - SURABAYA TERHADAP PENUMPANG KERETA EKSEKUTIF KORIDOR JAKARTA - SURABAYA}

\section{Djoko Prijo Utomo ${ }^{\mathrm{a}}$, Prasetyaning Diah Rizky Lestari ${ }^{\mathrm{a}}$, Sucipto ${ }^{\mathrm{a}}$, Asep Yayat Nurhidayat ${ }^{\mathrm{a}}$}

${ }^{a}$ Agency for the Assessment and Application of Technology, M.H. Thamrin, Jakarta, Indonesia

e-mail: djoko.prijo@bppt.go.id, diah.rizky@bppt.go.id, sucipto3215@bppt.go.id, asep.yayat@bppt.go.id

\begin{abstract}
Due to increasing travel of demands by trains in recent years, a large potential number of passengers for Jakarta - Surabaya corridor needs to be anticipated with adequate transportation system planning so that constraints on available transportation network system can be minimized. This paper analyses potential competition between demands of executive train passengers and Jakarta - Surabaya high - speed train passengers. This paper used travel time variables and ticket rates as independent variables between executive train passengers and high - speed train passengers. Therefore, stated preference methods and binomial logit models were used as tools for processing data. As a result, it is believed that the operation of Jakarta - Surabaya high - speed train would have a negative impact on the demand of executive train passengers on the same route.
\end{abstract}

Keywords: High - speed Train; Mode Choice; Stated Preference; Binomial Logit Model

\begin{abstract}
Abstrak
Seiring dengan meningkatnya jumlah permintaan perjalanan dengan kereta api dalam beberapa tahun terakhir, maka potensi besar jumlah penumpang di koridor Jakarta - Surabaya perlu diantisipasi dengan perencanaan sistem transportasi yang memadai. Hal ini bertujuan agar hambatan pada sistem jaringan transportasi yang tersedia dapat diminimalkan. Penelitian ini menganalisis potensi persaingan antara permintaan kereta penumpang eksekutif dan kereta cepat Jakarta Surabaya yang akan dibangun oleh Pemerintah. Penelitian ini menggunakan variabel waktu tempuh dan tarif tiket sebagai variabel independen antara penumpang kereta eksekutif dan kereta cepat. Metode stated preference dan model logit binomial digunakan sebagai alat untuk memproses data. Hasil menunjukkan bahwa pengoperasian kereta cepat Jakarta - Surabaya akan berdampak negatif pada permintaan kereta penumpang eksekutif pada rute ini.
\end{abstract}

Kata kunci: Kereta Cepat; Analisis Pemilihan Moda; Stated Preference; Model Logit Binomial 


\section{INTRODUCTION}

Investment on construction of national transport infrastructures, such as railways, is closely related with the socioeconomic development of a country 1). Jakarta and Surabaya are 2 (two) large cities in Indonesia with population of 9.59 million and 2.94 million, respectively. The two cities are magnet of the surrounding cities. Jabodetabek population is of 27.9 million, Kedungsepur is of 5.8 million and Gerbangkertasusila is of 9.1 million, therefore it reaches $31.25 \%$ of population in Java island. The economic potential of the three regions reaches $55.62 \%$ of the GRDP of all of Java (Java GRDP $47.27 \%$ of National GDP).

The interaction between the Jakarta area (Jabodetabek) and the Surabaya (Gerbangkertasusila) is relatively high, whereas the number of passengers of Jakarta - Surabaya airplane in 2017 was around 6.1 million passengers per year while executive train passengers was around 1.3 million passengers per year. It is estimated in 2058, that the number of passengers on the same route for airplanes will reach around 50 million passengers per year and train passengers will reach around 10.2 million passengers per year.

Currently, the railway line in Java has been using a narrow - gauge of $1067 \mathrm{~mm}$. The northern crossing of the Jakarta Surabaya train is way around $720 \mathrm{~km}$. The existence of an arch radius of less than 500 $\mathrm{m}$ which will hinder the speed of train operation. The high frequency of train travel across the North of Java Island has led to an effort to increase train speed become nonoptimal. In addition, another problem of number of level crossings exists has been around 2,000 locations. Jakarta - Surabaya via the northern route, served by various classes of trains i.e. economy class, business class and executive class using diesel locomotives. The fastest travel time of Jakarta - Surabaya is of 9 hours for the Argo Bromo executive train.

Passenger demand of Jakarta Surabaya both airplanes and trains have continued to increase resulting in saturation of the airport and the movement block of the train. For this reason, it is necessary to increase capacity of the transportation network between Jakarta - Surabaya. In terms of complementary services of the air transportation system, transportation modes are needed which are able to provide relatively fast travel times such as airplanes. Modes that are able to provide service time such as planes are trains.

Table 1.

Origin Destination Matrix of Executive Train Passengers In $2017^{2)}$

\begin{tabular}{ccccc}
\hline O/D & Gambir & Cirebon & $\begin{array}{c}\text { Semarang } \\
\text { Tawang }\end{array}$ & $\begin{array}{c}\text { Surabaya } \\
\text { Ps. Turi }\end{array}$ \\
\hline Gambir & & 476,800 & 324,200 & 650,022 \\
Cirebon & 440,123 & & 29,031 & 33,812 \\
$\begin{array}{c}\text { Semarang } \\
\text { Tawang }\end{array}$ & 299,261 & 26,798 & & 209,550 \\
$\begin{array}{c}\text { Surabaya } \\
\text { Ps. Turi }\end{array}$ & 600,020 & 31,211 & 193,431 & \\
\hline
\end{tabular}

From the table above, it can be seen that the number of executive train passengers of Jakarta - Cirebon - Semarang - Surabaya corridor reaches 3.3 million passengers/year. It means that the corridor has very potential for development. With the development plan of Jakarta - Surabaya high - speed train, there is the potential movement of passengers from executive train to high speed train.

In order for high - speed train operates safely; special lines are needed to separate it from other low - speed train operations. With the travel time of Jakarta - Surabaya getting shorter, there will be some passengers of executive class trains choosing to high - speed trains. It can help reduce the number of existing train movements in the executive class.

In addition, the utilization of the existing railroad for goods transportation is expected to encourage the transfer of goods by trucks on the highway to the railroad. Jakarta Surabaya freight transportation demand through the Pantura road is estimated at 39.77 million tons/year by 2030 . The utilization of the Jakarta - Surabaya high speed train needs to be encouraged as an alternative mass transportation mode to reduce the traffic volume and road load. If around $50 \%$ of freight transportation on the road is moved to the train, it will reduce the road traffic volume by around $30.5 \%$.

The large potential number of passengers of the Jakarta - Surabaya corridor needs to be anticipated with adequate transportation system planning so that constraints on available transportation network systems can be minimized. One of 
the efforts to increase transport capacity in the transportation network system is by providing fast railroad operations between Jakarta and Surabaya. The efforts to increase the speed of railways across North Java can be achieved by building an additional line of Jakarta - Surabaya high speed train. With the Jakarta - Surabaya high - speed train, and railroad operations, it will also increase the railroad capacity of North Java to increase by about 2 times the existing capacity because it will attract many passengers both from airplanes and executive class passengers.

\section{Literature Review}

High - speed rail (HSR) has been an important transport mode in recent years and constructed in many countries ${ }^{3)}$. In preference surveys, two approaches are known. The first approach is revealed preference (RP). The revealed preference technique analyses people's choices based on the existing reports. Using statistical techniques, it can be identified the factors that influence election. Revealed preference technique has a weakness, among others, in terms of estimating the individual response to a state of service that at present does not yet exist and can be a situation that is far different from the current situation ${ }^{4)}$.

Most stated preferences (SP) use experimental design to arrange alternatives presented to respondents. This design is usually made "orthogonal", meaning a combination of attributes that are presented varied independently of one another. The advantage is that the effects of each of the attributes that respond more easily identifiable ${ }^{5)}$.

Carried out SP research on Seoul-Daegu route air passengers supposing that KTX is introduced on the Seoul-Daegu route. After KTX was introduced, it was proven that there were actual changes in air transportation demand and passengers' preference compared to periods prior to the launch. To carry out the preference survey, access time, fare and the frequency of operation were set as variables ${ }^{6}$.

SP survey was also used to examine changes in air transport demand by the entry of low - cost carriers into domestic service, and with the beginning of operation of the Linear Chuo Shinkansen. Total fares, total travel time and frequency were considered as explanatory variables ${ }^{7}$.
$\mathrm{Li}, \mathrm{H}$., et al. stated about the impact of HSR on the domestic Chinese aviation passenger market. The dataset comprises a panel of 642 air and HSR routes from 2007 to 2014. During rapid HSR expansion from 2010 to 2014, the number of air passengers per route grew $32 \%$ for destinations that did not compete with $\mathrm{HSR}$, but fell $7 \%$ for routes that faced HSR competition. A difference in differences approach shows that the introduction of HSR leads to more than a $50 \%$ fall in air travel over two years. Increased frequency of daily HSR routes further contributes to economically large declines in air passengers ${ }^{8}$.

$\mathrm{Ma}, \mathrm{W}$., et al. discussed the effects of the busiest and most profitable high - speed rail (HSR) line in China the Beijing Shanghai HSR on the aviation markets paralleling this HSR line. In general, find that both air fare and air travel demand decreased significantly after the entry of the Beijing-Shanghai HSR. In particular, economy class air fares dropped more than business-class fares did, while the decline in the demand for business class travel was larger than it was for economy class travel. The frequency of and the number of seats on the HSR line were significantly and negatively associated with air travel demand, especially with demand for business class travel ${ }^{9)}$.

Zhang, Q., et al. compared air routes with different numbers of daily passengers, that HSR's effect on airlines is more salient in thin markets with low demand and insignificant in thick markets with high demand. This finding has policy implications for both HSR operators and airlines ${ }^{10}$ )

In addition to air transport, High - speed Train (HST) also has an impact on the other existing modes. Givoni concluded that shorter travel times and an increased level of service (a higher frequency and also improved travelling conditions) following the introduction of HST lead to changes in the modal share on the route and to the generation of new demand. The data presented by Givoni indicated that creation of the French Train a Grande Vitesse (TGV) line resulted in a $24 \%$ loss of market share for aircraft and an $8 \%$ reduction in car and bus travel. In Spain, a 27\% loss of market share was observed for aircraft and an 8\% loss for cars and buses ${ }^{11)}$.

Raturi, V., et al. studied the competition between HSR, conventional trains and buses in India market before and after HSR is 
introduced into the scenario and tries to derive some conclusions assisting in transportation policy decisions based on simulations performed for Bangalore Mysore corridor. This study is done with the aim to assess the viability of transport infrastructure investment in the form of HSR based on consideration that there will be price competition between different operators and the change in the existing market equilibrium due to the entry of the new mode ${ }^{12)}$.

In this study, SP research was carried out to analyse the potential competition between the demand of executive passenger train and Jakarta - Surabaya high - speed train. The result of this study can be used as reference to the making of transportation policy that benefits both parties which are competing.

\section{MATERIALS AND METHOD}

\section{Design of Stated Preference Technique}

Travelers generally choose the mode to be used by looking at the utility of the best mode. The modal utility in this study consists of the time and cost of travel. The utilities of the highest mode are if it has the lowest both of service time and travel cost.

SP technique is an approach to respondents to know their response to different situations. In this technique the researcher can fully control factors that exist in the hypothesized situation. Each respondent was asked about the response if they were faced with the situation given in the actual conditions (how are their preference to the options offered).

In this study, SP technique has utilized transport mode choice on the specific route based on statement of their preferences. Actually, SP techniques have been successfully applied to the transport choice problems. For air transport, researchers have also tried to apply SP techniques for demand analysis.

The selection of respondents in this study refers to the stratified random sampling method where the sampling process is by the process of dividing the population into strata (location of origin and destination), selecting simple random samples from each stratum and combining them into a sample to estimate the population parameters.

\section{Selecting of Choice Independent Variable}

In forming the model, the utility parameters used are different travel times (TD) and different travel costs (CD). Therefore, in the Stated Preference survey, interviews were conducted with prospective passengers at the train station by giving a number of questions that illustrate the hypothetical variations in the choice of modes offered.

Travel time is the travel time of the vehicle in minutes or hours, which is the time required to start the journey from the starting point to the station until arriving at the destination including the time of reporting the departure (check in, boarding), waiting at the station (waiting time), transit/ stop time and to the end of destination.

Fares are costs incurred for the payment of the transportation fee ${ }^{13)}$ in rupiah per person, which is the cost of the Jakarta Surabaya route. This variable is given three levels of value. The highest level is set at average air fare of 2016. The medium and low levels are set at values respectively $10 \%$ and $20 \%$ lower than the highest level's value. This was due to the assumption that if high speed train, a new mode of transportation, is introduced to the market, air carriers would set lower air fares to maintain their market share and competitiveness.

\section{Structure of the Questionnaire}

In this study, the attributes of travel are determined by conducting a special survey of the demand for travel attributes that are dominant in determining individual preferences for choosing a mode. The travel attributes are taken as many as two, which are also the top two attributes (dominant) based on the survey results of the attributes.

The main survey was carried out after the design of the SP questionnaire had met the requirements. One thing that needs special attention in the SP survey is the validity of survey data. Respondents must be guided to complete the questionnaire and are not allowed to choose more than one rating option. Besides that, it is also necessary to avoid data inconsistencies and fanaticism in one particular mode so that the users' response to changes in travel attributes and the addition of new modes can be well observed. This main survey examined the competition of the existing modes with one plan mode. Users of each mode only compare the existing modes that 
are commonly used with the plan modes offered. In this study, existing mode used by passengers is the Jakarta - Surabaya executive train. The existing travel time of this executive train is 600 minutes with fare (IDR) 450,000 . The values of each attribute level which were used in the survey given in table 2.

Table 2.

Values of Each Attribute Level

\begin{tabular}{|c|c|c|}
\hline \multicolumn{3}{|c|}{ Level of Attribute } \\
\hline & $\begin{array}{c}\text { Travel Times } \\
\text { Difference* (TD) }^{*} \text { (Minute) }\end{array}$ & $\begin{array}{c}\text { Travel Costs } \\
\text { Difference }^{*} \\
\text { (CD) (IDR) }\end{array}$ \\
\hline \multirow{16}{*}{ 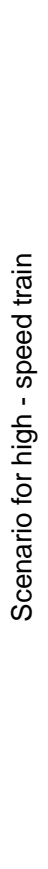 } & 60 & 50,000 \\
\hline & 60 & 100,000 \\
\hline & 60 & 200,000 \\
\hline & 60 & 300,000 \\
\hline & 240 & 50,000 \\
\hline & 240 & 100,000 \\
\hline & 240 & 200,000 \\
\hline & 240 & 300,000 \\
\hline & 360 & 100,000 \\
\hline & 360 & 200,000 \\
\hline & 360 & 300,000 \\
\hline & 360 & 400,000 \\
\hline & 420 & 150,000 \\
\hline & 420 & 250,000 \\
\hline & 420 & 350,000 \\
\hline & 420 & 450,000 \\
\hline
\end{tabular}

*The difference is compared to the existing executive train attribute

Table above explains the composition of the SP question attributes of respondents which were used in the survey questionnaire. For example, if high - speed train travel time is 60 minutes faster and the tariff is more expensive of IDR 50,000 than executive class train; consequently, respondents will make their choice whether to switch to high speed train or continue using the executive class train.

\section{Stated Preference Survey and Model Calibration}

SP technique bases the demand estimate on an analysis of responses to the choice of modes offered and is still in the planning stage. The implementation of the stated preference survey is done to see the respondent's preference to the level of the travel attribute offered. Respondents were asked to choose alternative options as they wanted.

The survey was conducted to respondents who travelled from Jakarta to Surabaya using an executive train with the aim to see the preferences of the attributes offered. From the survey that has been done then the data recorded include the age, gender, job, education, trip purpose, and the mode used to the station, in addition to other measurements asked for in general documentary records and the documentation of the stated preference test.

The stated preference data analysis is to decompile all preference into utility sections contained in each attribute being surveyed. The utility function is used to measure the attractiveness of each option (hypothetical scenario) given to the respondent.

The logit model is simply a log ratio of the probability of choosing a mode to the probability of not choosing a mode, and it is seen in the following equation.

$$
\log \left(\frac{P i}{1-P i}\right)=v(x i)
$$

where

$$
\begin{array}{ll}
P i & =\text { Probability of choosing mode } i \\
v(x i) & =\text { Utility of mode } i
\end{array}
$$

A mode is chosen if its utility increases for several reasons, among others, the first, utility itself is a function of the network effect, the more users, the more valuable the service, the higher the utility. Second, the utilization increases along with the decrease in user costs. Third, the technological advances that occur over time and as the number of users' increases will lower the relative cost.

An equation of a utility is given as follows.

$$
\log \left(\frac{P A}{1-P A}\right)=\beta o+\beta 1(c A-C T)+\beta 2(t A-t T)=v A
$$

where

$\begin{aligned} & P A=\text { Probability of taking new mode } \\ & c A, c T=\text { Cost of new mode, existing mode } \\ & t A, t T=\text { Travel time of new mode, existing } \\ & \text { mode } \\ & V A \quad \text { Utility of new mode } \\ & \text { The model can be translated using }\end{aligned}$ algebra and can be rewritten as follows: 


$$
\begin{gathered}
\frac{P_{A}}{1-P_{A}}=e^{V A} \\
P_{A}=e^{V A}-P_{A} e^{V A} \\
P_{A}\left(1+e^{V A}\right)=e^{V A} \\
P_{A}=\frac{e^{V A}}{1+e^{V A}}
\end{gathered}
$$

An object such as a vehicle does not have utility, it is characteristics of a vehicle that have utility. The introduction of $\boldsymbol{e}$ lets us do some aggregation. As noted above, it is thought of observable utility is a function of:

$$
v_{A}=\beta o+\beta 1(c A-C T)+\beta 2(t A-t T)
$$

Where each variable represents a characteristic of the auto trip. The value $\beta 0$ is termed an alternative specific constant. Most modelers say it represents characteristics left out of the equation.

\section{RESULT AND DISCUSSIONS}

This research was conducted to investigate how the travel characteristics of the executive class passengers as well as how the potential and model of the shift to the Jakarta - Surabaya high - speed train mode. The planned route used is the main route of Java Island starting from Jakarta Cirebon - Semarang - Surabaya. The primary data collection survey in this study used a stated preference technique where respondents were interviewed and survey questionnaires were filled out. The survey itself was carried out at Gambir Station, Gubeng Station and Pasar Turi Station.

From the results of a survey that has been done, it can be seen the characteristics of respondents vary from gender, education, employment, income and travel purpose. Male gender respondents were $66.96 \%$ and women were $33.04 \%$. For the education level of $46.78 \%$ for undergraduate, $33.48 \%$ for high school and so on. For employment, $32.62 \%$ for employee, $21.02 \%$ for businessman and others. For income levels, $46.78 \%$ for IDR $<6,000,000$, and $33.05 \%$ for IDR $6,000,000$ - 12,000,000. Whereas the majority purpose of travel is for working at

\begin{tabular}{|c|c|}
\hline Variable & Percentage \\
\hline Gender & Male: $66.96 \%$, Female: $33.04 \%$ \\
\hline \multirow{5}{*}{$\begin{array}{l}\text { Education } \\
\text { Level }\end{array}$} & Junior high school: $6.87 \%$ \\
\hline & Senior high school: $33.48 \%$ \\
\hline & Diploma: 5.58\% \\
\hline & Bachelor: $46.78 \%$ \\
\hline & Postgraduate: $5.15 \%$ \\
\hline \multirow{5}{*}{ Job } & Government employee: $10.73 \%$ \\
\hline & Employee: $32.62 \%$ \\
\hline & Businessman: $21.02 \%$ \\
\hline & Student: $11.59 \%$ \\
\hline & Other :24.03\% \\
\hline \multirow{4}{*}{$\begin{array}{l}\text { Income } \\
\text { Level }\end{array}$} & IDR $<6,000,000: 46.78 \%$ \\
\hline & IDR $6,000,000-12,000,000: 33.05 \%$ \\
\hline & IDR $12,000,000-18,000,000: 8.58 \%$ \\
\hline & IDR > 18,000,000: $4.72 \%$ \\
\hline \multirow{6}{*}{$\begin{array}{l}\text { Trip } \\
\text { purpose }\end{array}$} & Work: $57.51 \%$ \\
\hline & Social: $24.03 \%$ \\
\hline & Recreation: $5.58 \%$ \\
\hline & Business: $6.44 \%$ \\
\hline & Study: $3.43 \%$ \\
\hline & Other: $3.00 \%$ \\
\hline
\end{tabular}
$57.51 \%$. The details can be seen in the Table 3 below.
Table 3.

\begin{tabular}{|c|c|c|}
\hline \multirow[b]{2}{*}{ Classifications } & \multicolumn{2}{|c|}{ Respondents } \\
\hline & $\begin{array}{c}\text { No. of } \\
\text { respondents }\end{array}$ & $\begin{array}{c}\text { Share } \\
\text { rate (\%) }\end{array}$ \\
\hline Private car & 80 & $34.3 \%$ \\
\hline Station taxi & 24 & $10.3 \%$ \\
\hline Online taxi & 58 & $24.9 \%$ \\
\hline Bus & 2 & $0.9 \%$ \\
\hline Official car & 10 & $4.3 \%$ \\
\hline Motorcycle & 22 & $9.4 \%$ \\
\hline Other & 10 & $4.3 \%$ \\
\hline Public Transport & 19 & $8.2 \%$ \\
\hline No response & 8 & $3.4 \%$ \\
\hline Total & 233 & $100 \%$ \\
\hline
\end{tabular}

General Survey Result Data

Table 4.

The Modal Share of Access to Station

From table 4, it can be seen that the mode used to get to the station is dominated by private vehicle at $34.3 \%$, online taxi at $24.9 \%$, taxi at $10.3 \%$, motorcycle at $9.4 \%$ and so on. 
Based on the survey, the average fare of executive class trains of Jakarta - Surabaya which paid by passengers can be seen in the table 5.

Table 5.

Average Fare of Executive Train Jakarta Surabaya from Survey Result

\begin{tabular}{lccccc}
\hline \multirow{2}{*}{$\begin{array}{c}\text { Mode \& } \\
\text { Route }\end{array}$} & \multicolumn{5}{c}{ Level of Income (IDR) } \\
\cline { 2 - 6 } & $\begin{array}{c}<\mathbf{6} \\
\text { million }\end{array}$ & $\begin{array}{c}\mathbf{6 - 1 2} \\
\text { million }\end{array}$ & $\begin{array}{c}\mathbf{1 2 - 1 8} \\
\text { million }\end{array}$ & $\begin{array}{c}\mathbf{> 1 8} \\
\text { million }\end{array}$ & Average \\
\hline $\begin{array}{l}\text { Executive } \\
\text { Train } \\
\text { Jakarta - } \\
\text { Surabaya }\end{array}$ & 438,080 & 436,310 & 417,000 & 439,820 & 433,400 \\
\hline
\end{tabular}

Calibration is the process of estimation of the parameter value in an equation that gives the best results or closest to the observations in the field. Calibration of a regression equation will produce numerical values of the constants and the regression coefficients of the equation. The results of the calculation of the calibration can be seen in the following Table 6.

Table 6.

The Result of Model Calibration

\begin{tabular}{lrr}
\hline \multicolumn{1}{c}{ Variable } & Model Calibration \\
\hline \multicolumn{1}{l}{ Constants: } & $\mathrm{a}_{0}$ & 5.437937077 \\
& $\mathrm{t}$-stat & 17.25630346 \\
\hline \multicolumn{2}{l}{ Independent Variable: } \\
Time Different $\left(\mathrm{a}_{1}\right)$ & 1.616524694 \\
$\mathrm{t}-\mathrm{stat}$ & 23.97753423 \\
Cost Different $\left(\mathrm{a}_{2}\right)$ & $-6.31098 \mathrm{E}-05$ \\
$\mathrm{t}-\mathrm{stat}$ & \\
Multiple $\mathrm{R}$ & 0.781492137 \\
$\mathrm{R}^{2}$ & 0.610729960 \\
\hline
\end{tabular}

On binomial logit difference model, attributes in time travel (travel time) has a positive sign (+) on all alternative equations. This means that if there is an increase in the ratio between the airplane travel time trip and high - speed train (executive train travel time trip increased or high - speed train decreased) then it will result in a probability of selection modes an executive train decreases, and probability of high - speed train increases.

Moreover, attributes in travel costs has a negative sign (-) on all alternative equations. This means that if there is a decrease in the ratio between the executive train travel cost and high - speed train (the cost of executive train increases or the cost of high - speed train decreases) then it will result the probability of selection modes an executive train decreases and high - speed train increases.

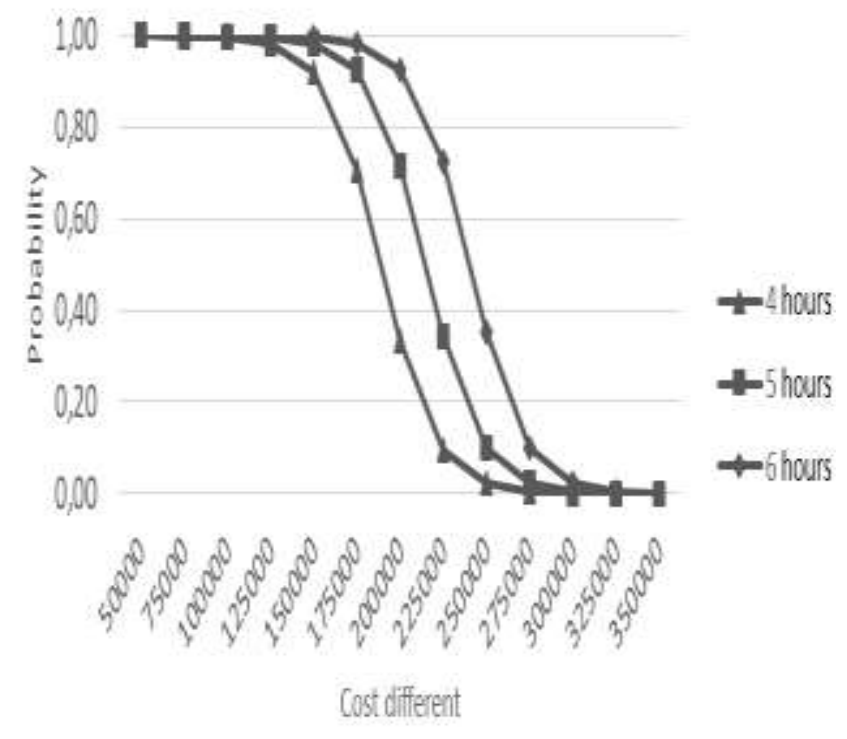

Figure 1

Probability Mode Choice Executive Train and High - speed Train (IDR)

Figure 1 represents probability mode choice of executive train and high - speed train. It can be seen that distinction probability selection mode of an executive train with a high - speed train from Jakarta Surabaya appears clearly.

The probability of choosing executive train based on high - speed train fares and travel time structure has been observed, and from the time when the high - speed train is open for traffic, it can be assumed that the new rail system will reduce aviation demand. As medium speed train fare and travel time same (shown in Table 7), the probability that executive train will be chosen over rail.

Table 7.

The Probability of Transport Modal Choice Based on the High - speed Train

\begin{tabular}{ccc}
\hline & $\begin{array}{c}\text { Probability of } \\
\text { choosing high } \\
\text { - speed train }\end{array}$ & $\begin{array}{c}\text { Probability of } \\
\text { choosing } \\
\text { executive train }\end{array}$ \\
\hline Passengers & 0.5042 & 0.4958 \\
\hline
\end{tabular}

Table 7 shows that the operation of the Jakarta - Surabaya high - speed train with a 
travel time of 6 hours is faster with a difference in tariffs of more than IDR 240,000 , leads the probabilities of the executive passenger trains that will move using high - speed trains are into $50.42 \%$, thus potentially causing negative impacts for executive class trains because it will cause a decrease in the number of passengers on that route.

\section{CONCLUSION}

This paper examines the impact of the operation of high - speed train on executive passenger train demand on the Jakarta Surabaya corridor. The increasing number of passengers, both airplanes and train passengers of Jakarta - Surabaya route is very high, as seen from the number of passengers between the 2 cities reaching 6 million passengers for airplane passengers and 1.2 million passengers for executive class passengers.

First, factors that greatly affect passengers in determining the mode to be used, such as travel time and tariffs are needed to be considered. These are the main factors in determining mode choices. Next, an analysis of modal choice between executive class trains and the Jakarta Surabaya high - speed train is conducted to find potential train passenger demand that would move using this high - speed train.

Further investigation revealed that the decline in demand by executive class passengers resulted from an increase in the high - speed train frequency and high speed train rates. It is believed that the operation of this high - speed train can reduce the demand for airplane passenger travel due to its time of travel and competitive rates.

From the analysis with the operation of the Jakarta - Surabaya high - speed train with a travel time of 4 hours and a tariff of IDR 700,000 it will cause the probability of executive train passengers who move to the Jakarta - Surabaya high - speed train around $50 \%$. By seeing this condition, government needs to take action to anticipate movements' executive class trains which will be halved so that the existing railroad industry can continue to carry out its operations.

\section{ACKNOWLEDGEMENT}

The authors would like to express their gratitude to the Indonesian Ministry of Transportation and Centre of Technology for System and Infrastructure of Transportation BPPT for supporting this study under the program of Pre-Feasibility Study of Jakarta Surabaya Corridor Railway Improvement Study 2017.

\section{REFERENCES}

1. Chen, Z., Xue, J., Rose, A. Z. \& Haynes, K. E., The impact of highspeed rail investment on economic and environmental change in China: $A$ dynamic CGE analysis, Transp. Res. Part A Policy Pract. 92, 2016, p232245.

2. Directorate General of Railways Indonesian Ministry of Transportation, Boarding - Alighting Data of Executive Train Passengers, 2017.

3. Levinson, D. M., Accessibility impacts of high-speed rail, J. Transp. Geogr. 22, 2012, p288-291.

4. De Dios Ortúzar, J. \& Willumsen, L. G., Modelling Transport, John Wiley \& Sons, Ltd, 2001.

5. Pearmain, D., Swanson, J., Kroes, E. P. \& Bradley, M., Stated Preference Techniques: A Guide to Practice, Steer Davies Gleave and Hague Consulting Group, 1990.

6. Park, Y. \& Ha, H. K., Analysis of the impact of high-speed railroad service on air transport demand, Transp. Res. Part E Logist. Transp. Rev. 42, 2006, p95-104.

7. Inoue, G., Ono, M., Uehara, K. \& Isono, F., Stated-preference analysis to estimate the domestic transport demand following the future entry of LCCS and the inauguration of the Linear Chuo Shinkansen in Japan, J. Air Transp. Manag. 47, 2015, p199217.

8. Li, H., Strauss, J. \& Lu, L., The impact of high-speed rail on civil aviation in China, Transp. Policy 74, 2019, p187-200. 
9. Ma, W., Wang, Q., Yang, H., Zhang, A. \& Zhang, Y., Effects of BeijingShanghai high-speed rail on air travel: Passenger types, airline groups and tacit collusion, Res. Transp. Econ. 74, 2019, p64-76.

10. Zhang, Q., Yang, H. \& Wang, Q., Impact of high-speed rail on China's Big Three airlines, Transp. Res. Part A Policy Pract. 98, 2017,p77-85.

11. Givoni, M., Development and Impact of the Modern High-speed Train: $A$ Review. Transp. Rev. 26, 2006.
12. Raturi, V., Srinivasan, K., Narulkar, G., Chandrashekharaiah, A. \& Gupta, A., Analyzing Inter-modal Competition between High Speed Rail and Conventional Transport Systems: A Game Theoretic Approach, Procedia Soc. Behav. Sci. 104,2013, p904 913.

13. Lee, J. K., Yoo, K. E. \& Song, K. H., A study on travelers' transport mode choice behavior using the mixed logit model: A case study of the Seoul-Jeju route, J. Air Transp. Manag. 56, 2016, 131-137. 
(halaman ini sengaja dikosongkan) 